\title{
Must Refugees Return?
}

\section{Mollie Gerver}

Forthcoming in Critical Review of International Social and Political Philosophy

\begin{abstract}
It is widely accepted that states have a right to control immigration, but must accept refugees at risk in their home countries. If this is true, perhaps states have a right to deport refugees once their lives are no longer at risk in their home countries. I raise three types of arguments against this claim, and in support of refugees' right to remain. Citizenship-based arguments hold that refugees have a right to obtain citizenship, and with citizenship comes the right to remain. Plans-based arguments hold that refugees have a right to plan their lives, and they will struggle to plan without the right to remain. Reciprocitybased arguments hold that refugees have a right to reciprocal relationships with citizens, far easier if they know they can remain. I reject the first two arguments, and defend the third.
\end{abstract}


It is widely accepted that states have a right to control who enters their territory, deciding how many workers join the economy, how many residents join the citizenry, and how many students, patients, and pedestrians join the state's schools, hospitals, and roads. Even those who insist that states are obligated to provide citizenship to long-term residents often accept that states have a right to determine who can become a long-term resident, and so who will be entitled to citizenship later. ${ }^{1}$

It is also widely accepted that states, although holding the right to control immigration, must make exceptions for refugees. States do not have a right to turn away those whose life or basic liberty will be at risk if they return home, including those fleeing persecution, famine and civil war. ${ }^{2}$

If states have a general right to control immigration, but refugees are an exception because their lives or liberty are at risk, perhaps states can require that refugees return home once their lives or liberty are no longer at risk. This logic, supported by some philosophers (Hathaway and Neve, 1997 and Miller, 2005, pp. 202-203), is the norm in a range of countries. In 2008 Ghanaian Minister of Interior Kwamena Bartels announced that Liberian refugees would be required to return home, as the Liberian Civil War had ended (Omata, 2011). In 2013 the Kenyan government insisted that Somali refugees begin repatriating, including those who had lived in Kenya most of their adult lives (Hamilton, 2013). In 2016 the German government announced that Syrian refugees would be required to return home once the war in Syria ended (Rinke, 2016).

This article objects to these policies and defends the claim that refugees have a right to remain even when returning is safe. After setting out some assumptions in Section 1, Section 2 presents and rejects four arguments which attempt to explain why refugees have a right to remain. The first three arguments relate to citizenship: refugees have a right to eventually obtain citizenship in their adopted states, and with citizenship comes the right to remain. The fourth argument relates to plans: refugees have a right to plan for the future, and planning requires the ability to remain. Section 3 presents a 
more promising argument: refugee have a right to remain because they have a right to enter reciprocal relationships with citizens. Such reciprocity is easier to develop if citizens are certain that refugees will not be deported once returning is safe.

\section{Some assumptions}

Throughout the article I will assume that states usually have a right to control immigration, and consider why refugees still have a right to remain even if this assumption is true. However, nothing in my argumentation is dependent on this assumption: if one supports open borders, this too is compatible with my argumentation. My goal is to demonstrate why supporting states' right to control immigration needn't preclude refugees' right to remain.

If refugees have a right to remain, I assume this means states have a weighty moral reason to provide refugees the legal status to remain, and states are not morally permitted to revoke this status whenever they desire that refugees leave. In other words, states are not permitted to invoke their general right to control immigration as the sole justification for requiring that refugees eventually leave. This is consistent with the claim that there may be other justifications for requiring that refugees leave. For example, if providing refugees the right to remain created detrimental economic strife for the host country, such that citizens could not obtain basic necessities for survival, perhaps citizens' right to survival could trump refugees' right to remain. ${ }^{3}$

This is a fairly standard understanding of 'rights' within debates on immigration ethics. For example, Joseph Carens and Kieran Oberman claim that all individuals have a right to cross borders, but stipulate that this right could be curtailed if it somehow undermined citizens' access to basic necessities (Carens, 1987, p. 260; Oberman, 2016, p. 33). ${ }^{4}$ Even those who claim refugees have a right to asylum might use the word 'right' in this non-absolute sense. For example, if a state learned that accepting millions of refugees would overwhelm basic provisions for all, then the rights to basic provisions could outweigh refugees' rights to asylum. 
In discussing refugees' right to remain, I assume that refugees include all those who the UN claims should be given asylum. These are individuals who have a wellfounded fear of persecution in their home countries (1951 Convention). I also assume that refugees include those fleeing for their lives or basic liberty, whether their lives or liberty are at risk from food insecurity, a natural disaster, or general violence. ${ }^{5}$ I assume that coercing such 'survival migrants' (Betts, 2010) to leave is unethical if the state has the capacity to accept such individuals, and if accepting these individuals is the only way to ensure that their rights to life and liberty are protected. This claim is supported not only by philosophers who believe in open borders, such as Joseph Carens (1987), but by those who defend states' right to exclude immigrants, such as Matthew Gibney (2004), David Miller (2005), and even some states themselves (Betts, 2010). ${ }^{6}$ As such, it serves as a 'minimal ethical standard' (Hidalgo, 2015) for which individuals have a right to asylum, leaving open the question of whether these individuals must eventually return home.

\section{Four arguments and their limits}

There are four promising arguments for why refugees have a right to remain, but all four have limitations.

\subsection{State membership}

This argument begins with the premise that all individuals have a right to membership in a state. An individual is no longer a member of her home state if her membership has been repudiated. Her membership can be repudiated when a core feature of her identity is rejected by her home state, and this can occur if she is persecuted because of her religion, race, politics or social membership. She therefore has right to membership in a new state, rather than mere temporary asylum. For her to be a true member she must eventually obtain citizenship. Once she is a citizen, she has a right to remain even if returning to her home country is safe (Cherem, 2016, p. 191-192; Lister, 2013, p. 662 and 669-670; Walzer, 1983, p. 48). 
One problem with this State Membership Argument is that a person can be persecuted but remain a member of the state, so long as they are persecuted by independent militias who do not represent the state. Such a person's bond with their government remains intact if their government is doing everything to stop the militias' actions. Once the government stops the militias, refugees can perhaps return home.

One proponent of the State Membership Argument, Matthew Lister, addresses this objection. He argues that when militias target individuals, the militias usurp the state's authority, essentially becoming the state. The state therefore repudiates victims' membership, because the state has become the militias engaging in persecution (Lister, 2013, p. 662). For example, when Hutu militias targeted Tutsi citizens during the Rwandan Genocide, the power of the original Rwandan government became usurped, and the true state was represented by Hutu militias. The state - represented by the Hutu militias - repudiated the membership of Tutsi residents, and these residents therefore had a right to citizenship elsewhere, and so a right to remain elsewhere.

One reason to reject this argument is that it rests on a view of the state rejected by many refuges themselves. When refugees flee a militia that has usurped the government, a separate government may remain in exile. When refugees feel a strong bond to this government-in-exile, and feel this government is the true representative of the state, they may plan to return to their state when this government-in-exile regains power. From refugees' own perspective, their bond with their state remains strong. Just as those fleeing famine or natural disasters still maintain a bond with their state, even if the government is powerless to stop the famine and natural disaster, refugees fleeing militias can maintain a bond with their state, even if the government is powerless to stop the militias. If they maintain a bond, and feel they remain members of their state, perhaps they can be required to return once their original government becomes reinstated.

Even if one rejects this response, the State Membership Argument is still limited in scope: it does not explain why those fleeing conditions other than persecution have a 
right to remain. Those fleeing natural disasters or general violence are not necessarily persecuted, and so their membership has not been repudiated. They therefore do not have a right to citizenship elsewhere, according to this argument. If this is true, then it seems many individuals who are accepted as refugees - including Syrian refugees fleeing general violence, or Ethiopian refugees fleeing famine - do not have a right to remain. If we wish to find an argument in support of these refugees' right to remain, another argument is necessary.

\subsection{Justice}

This argument holds that that all individuals have a right to citizenship in a state that follows minimal principles of justice. A state that persecutes minorities fails to follow minimal principles of justice, but so does a state forcing individuals to flee an unjust war it began, or a famine it is responsible for. Such a state's refugees have a right to citizenship in a just state, and so a just state ought to provide them both asylum and citizenship. At the very least, it cannot deny citizenship based solely on its general right to control immigration. ${ }^{7}$

Moreover, even when a host state is not entirely just, it ought to provide citizenship to refugees if it is more just than the state from which refugees fled. For example, when Rwandan refugees fled to Uganda in 1994, Uganda was a more just state than Rwanda at that moment, even if a less just state than, say, Ghana. If Uganda could provide citizenship to refugees without incurring significant costs, and no other state was willing to provide this citizenship, it had a duty to provide citizenship. With citizenship comes the right to remain, and so Rwandan refugees had the right to remain.

While this Justice Argument is seemingly promising, it includes a controversial premise. It presumes individuals have a right to citizenship in a just state. It may be that individuals merely have a right to residency in a just state, or basic necessities in some state. If one holds that the right to asylum is merely the right to access residency in a just state, or basic necessities in some state, then refugees do not have a right to 
obtain citizenship after they have fled. They merely have a right to asylum until their home state becomes just, or until they can obtain basic necessities in their home state.

Moreover, even if refugees do have a right to citizenship in a just state, many refugees are fleeing states that are perfectly just. For example, those fleeing natural or economic disasters might find their lives threatened from destitution, and so are refugees according to a range of views, but they are not always fleeing an unjust state if their state is attempting to protect its citizens lives, and simply lacks the resources to do so. Similarly, a refugee leaving behind a country without sufficient medical care may be leaving behind a just state that simply lacks sufficient medical resources through no fault of its own. Such was possibly the case with N, an HIV-positive woman who arrived in the UK in 1998, eventually requesting humanitarian protection on the grounds that she lacked access to anti-retroviral treatment in Uganda (Carter, 2008). Uganda was not necessarily unjust if it simply lacked the resources to provide HIV treatment to all. Assuming $\mathrm{N}$ was a refugee in the sense I defined - someone who has a right to remain because returning home is life-threatening - and assuming the UK could have easily permitted her to remain, she had a right to asylum even though she maintained citizenship in a just state. If she already had citizenship in a just state, she did not have a right to citizenship in the UK on these grounds alone.

Perhaps the reason refugees like $\mathrm{N}$ have a right to citizenship is not because they lack citizenship in a just state, but because they lack access to the practice of citizenship in any state. When $\mathrm{N}$ arrived in the UK she relied on the UK's National Health Services (NHS) to survive, and so could not move back to Uganda and access voting rights, an essential component of what it means to be a citizen. $N$ therefore had a right to citizenship in the UK, ensuring she could be a citizen in practice, and not merely on paper. ${ }^{8}$

This argument, however, merely demonstrates that $\mathrm{N}$ had a right to vote in UK elections, and access the other benefits of citizenship, such welfare benefits, the ability to run for office, and assurance that she would not face deportation so long as she was 
dependent on the NHS for survival. She could have a right to the benefits of citizenship while she was a refugee, and then lose these rights if these benefits became unnecessary when returning was safe. ${ }^{9}$ If such a policy would give her access to the practices associated with citizenship, then she did not have a right to citizenship itself, and so did not have a right to remain if returning home became safe.

Rather than claiming refugees have a right to citizenship because of what they lost when they fled, perhaps refugees have a right to citizenship because of what they gained when they arrived.

\subsection{Social membership}

In general, individuals gain 'social membership' (Carens, 2013, p. 158; Miller, 2016, p. 123; Rubio-Marin, 2000, p. 8). after they have lived in a country for a significant number of years. If individuals are social members, they have come to interact with others in a manner that gives rise to certain moral claims. One claim is relational: if an individual has come to make new friends whom she is emotionally dependent on, and who are dependent on her, she has become an integral part of a relationship that is of value, and which gives rise to the claim to remain to continue this valuable relationship. ${ }^{10}$ Another moral claim is reciprocal: if an individual has paid taxes to the government for over a decade, or contributed to a local community center through volunteer work, she has a stronger claim to reap some of the benefits she has contributed in the past (Miller, 2016, p. 124). Some of these benefits cannot be reaped without citizenship, including the benefits of accessing welfare for as long as necessary, and the benefits of remaining to continue friendships, even when returning is safe. ${ }^{11}$

Refugees who have fled their home countries have a right to remain for similar reasons. After some years have passed, they have likely developed social ties that give rise to moral claims which non-residents do not possess. Just as long-term residents have a right to remain, long-term refugees have a right to remain as well. ${ }^{12}$ 
This Social Membership Argument has been adopted in many wealthier countries. In the United States refugees can apply for permanent residency after a year, and then apply for citizenship if they have lived in the country as permanent residents for at least five years (U.S Citizenship and Immigration Services). In Germany all individuals, including refugees, are entitled to citizenship if they have lived in the country as a permanent resident for eight years and fulfill certain conditions, such as proof of integration via a naturalization test (Federal office of Migration and Refugees). If states allow long-term non-refugees to remain, they ought to allow long-term refugees to remain as well.

There is a problem with the above reasoning. Even if states have a duty to provide citizenship to those who have lived in the country for many years, perhaps they needn't let individuals remain in the country for many years. So long as states do not permit refugees to remain in one country for more than a given number of years, many refugees will not become social members, and so will not have a right to citizenship based on social membership alone. Nor would such a policy violate refugees' right to protection: so long as some state was willing to provide a temporary visa, then refugees could maintain protection throughout the period when returning was unsafe. This would be possible if a given country provided refugee status for five years, after which another state took over providing asylum for an additional five years, followed by a third country if necessary, and so forth.

A policy which required refugees to move every few years could be modeled after today's guest worker programs, which allow migrant workers to remain in one country for a given number of years - often fewer than the years required for citizenship - after which workers leave and seek a visa elsewhere for a specified number of years. Indeed, if we view refugees as all individuals whose lives would be at risk if they returned home, including those at risk from life-threatening unemployment, we might view such guest worker programs as including short-term asylum. For example, Thailand, Japan, and Israel each offer short-visas to migrant workers, including some workers who would otherwise die of malnutrition without 
such visas (Harding, 2016; OECD, 2011; Weiler et al, 2017). Thailand, Japan, and Israel can defend their requirement that migrants leave, even though they would die of malnutrition in their home countries, by claiming migrants can access another visa elsewhere once their visas lapse, and migrants have not stayed long enough to gain social membership locally.

If such a policy is wrong, and we ought not force refugees to move from country to country every few years, a good theory will explain why.

\subsection{Plans}

The Plans Argument begins with a premise, supported by a range of philosophers, that a minimally decent life includes the ability to enter social, economic, and romantic relationships with others. Individuals struggle to gain these and other valuable relationships if they cannot remain where they are. They struggle to fulfill plans to enter professional relationships if they do not know where they will live tomorrow, and they struggle to form social relationships if they cannot remain in the same city, town, or neighborhood. Forcing individuals to leave can also undermine a range of basic abilities that enhance relationships with others, like the ability to spontaneously run into a new friend at the park one frequents regularly, or the ability to build up a business with loyal customers in one location. Just like we are dependent on continuing to own our computer, phone, or stove to write, call, or cook, we can be dependent on continuing to be in our homes, cities, or public spaces to live, work, and interact. If forcing individuals to leave their homes, cities, or public spaces undermines their abilities and plans, and others can protect these abilities and plans at negligible costs, then others have a duty to do so. Others should therefore permit individuals to remain when this involves negligible costs (Goodin, 1991, pp. 53-57; Nine, 2018; Stilz, 2011, pp. 582-87; Stilz, 2013, pp. 336-341).

This broader claim has clear implications for refugees: just as it is wrong in general to force individuals to leave their current location, because this will destroy their plans and abilities to enter relationships with others, it is wrong to force refugees to leave 
their first country of asylum, because this will destroy their plans and relationships with others. In other words, refugees have a right to remain not because of close ties they gained in a host state, but because they have a right to gain close ties in a host state.

I believe this theory takes us closer to defending refugees' right to remain. However, it would help if we had an additional theory explaining why the sorts of ties arising when one remains are better than the ties arising when one moves. In a world where refugees were required to move every five years, they could still gain some ties, entering romantic relationships lasting five years, friendships lasting five years, and employment contracts lasting five years. In such a world refugees could even plan for their future if they were aware they would leave after five years. While they could not plan for long-lasting attachments, they could at least gain temporary attachments for a limited period of time. If one holds that humans have a right to mere temporary attachments for a limited period of time, it seems refugees have no right to remain.

In what follows, I explain why even temporary attachments are difficult to obtain when one moves every few years. Assuming that all humans at least have a right to short-term ties, refugees have a right to remain.

\section{Reciprocity}

This argument assumes, as stipulated in the introduction, that refugees are those whose right to life or liberty are undermined in their home countries. Having one's life and liberty undermined is bad in itself, and this explains why refugees have a right to asylum. It is additionally bad because it undermines long-term attachments: it is difficult to marry, work, or form friendships if one is constantly escaping persecution and disaster. Finally, it is bad because it can undermine the ability to enter even shortterm relationships with others. This is because security and liberty are often essential for reciprocal relationships. 
A reciprocal relationship, as I define it here, occurs when $X$ provides an offer to $Y$ with the expectation that $\mathrm{Y}$ will later provide an offer back, which $\mathrm{Y}$ later provides back with the expectation that $\mathrm{X}$ will later provide another offer back, which $\mathrm{X}$ later provides with the expectation that $\mathrm{Y}$ will later provide another offer back, and so forth. I put aside broader understandings of reciprocity, where $\mathrm{X}$ provides a good to $\mathrm{Y}$ which is proportionate to the good $\mathrm{Y}$ provided, but which $\mathrm{X}$ would have provided without the expectation that $\mathrm{Y}$ would again provide a good in the future. ${ }^{13} \mathrm{In}$ the instances of reciprocity I have in mind, both $\mathrm{X}$ and $\mathrm{Y}$ would not provide their respective offers if they believed the other would not provide an offer back, and both are aware that the other would not provide their respective offers back if they believed the other would not provide an additional offer in turn. ${ }^{14}$

For an example of such reciprocity, imagine an employer provides training to an employee with the expectation that the employee will continue to work, and the employee continues to work with the expectation of a promotion in the future, and the employer later provides a promotion with the expectation that the employee will remain in the company and work. Both the employer and employee are aware that the other is providing their respective goods with the expectation that she will provide her respective goods in return. Similarly, when a bank offers a loan, it does so with the expectation that the borrower will pay the money back, and the borrower will often pay the money back with the expectation that she can then qualify for another loan in the future, itself provided by the bank with the expectation that the borrower will pay the money back, which the borrower might do with the expectation of qualifying for a loan again in the future. Both parties are aware that the other party is acting as she does - or possibly acting as she does - with the expectation that the other will reciprocate.

Reciprocal relationships are not limited to financial transactions. The awkward start of friendships and romances are full of reciprocity. If I want to be someone's romantic partner, I might invite them out for a drink with the hope they will invite me for a drink in the future; had I been certain they would never ask me out later, I might be 
less inclined to ask them out now. If I invited them out for a drink, and they wanted to enter a romantic relationship, they might invite me to another drink later, and would not have invited me for this other drink if they suspected I would not later reciprocate in turn, inviting them to some other event with the expectation they would invite me back, and so forth.

If employment, loans, and romance are easier to develop with reciprocity, they are easier to develop with certain expectations of the future. The moment we think that another will not reciprocate in the future, we have less reason to reciprocate ourselves in the present, bringing the relationship to an end. One reason we might suppose another will not reciprocate in the future is that they will not be able to, such as when an employer suspects an employee will become ill, leave the city, or find a better job elsewhere. Another reason someone might not reciprocate is because we think they think we will not reciprocate. This can prevent even a short-term relationship from developing.

For example, imagine you will remain the country for the next four years, and during this time you will have time to engage in 100 reciprocal transactions: I will give you a loan, you will pay this back with the expectation I will give you another loan, which you will also pay back with the expectation I will give you yet another loan, up until 100 loans. I am less likely to give the $100^{\text {th }}$ final loan if I think you are less likely to pay it back, on account of leaving after this final loan. If you know I will not give you this $100^{\text {th }}$ loan, you are less likely to pay back the $99^{\text {th }}$ loan, knowing that you will not gain the $100^{\text {th }}$ loan. If I know you are less likely to pay back the $99^{\text {th }}$ loan, I am also less likely to give you this loan. If you know I will also not give you the $99^{\text {th }}$ loan, you are also less likely to pay back this $98^{\text {th }}$ loan, knowing there is no additional loan to come. I, in turn, am less likely to give you this $98^{\text {th }}$ loan, and so forth, until there are no loans to give at all. The more we both know the precise end of our interactions, and the sooner this end is, the quicker and more likely this reciprocal relationship unravels, preventing any relationship at all. If we do not know the precise end, and suspect it 
will continue indefinitely or for a long and unspecified time, the reciprocal relationship will be stronger and longer. ${ }^{15}$

This knowledge that another will likely reciprocate in the future has been termed the 'shadow of the future' (Axelrod, 2006, Ch. 10). If the shadow of the future helps individuals develop reciprocal relationships, and such relationships help individuals obtain even short-term financial, professional, and social relationships, then a shadow of the future helps individuals obtain short-term financial, professional, and social relationships.

One of the disadvantages of living in a country with a high risk of death and persecution is that the shadow of the future is shorter, and so the possibility of relationships lower. A Nuer businesswoman in Juba who faces potential death by persecution will struggle to persuade a potential investor to provide investment for her small business, as the investor may be uncertain if she will be around to generate a profit later on. A farmer suffering from severe malnutrition in Burundi will struggle to obtain a loan to buy seeds, because a lender may be uncertain whether the farmer will survive until next season and pay him back. A student in Syria will struggle to obtain employment if an employer fears the student will flee bombs and terrorists at the first opportunity. Even if the businessman, farmer, and student have no plans to leave, it is enough that the investor, lender, and employer suspect they will leave for them to hesitate to provide them investments, loans, or employment. In other words, the problem is not merely that investment relationships are short-lived, or that loans are one-off, or that jobs are temporary: it is that any investments, loans, or jobs are difficult to obtain when the shadow of the future is short.

Similar problems arise in forming new romantic relationships. If romance begins when one person invites another out for a coffee, with the hope that the other will reciprocate, romance can be difficult if the other will unlikely reciprocate because they may not be around the next day. The inability to predict the future, and the suspicion that the future will end with death or displacement, makes it difficult to enter 
relationships that require prediction and stability. Without prediction and stability, the relationships are not merely short-lived: they can fail to take rise at all.

Without such relationships, an important set of interests are set back. One interest is financial: when an individual has no access to credit, jobs, or romance, she may struggle to access food, shelter, and economic support. ${ }^{16}$ Another interest is intrinsic to the relationships themselves. There is a value in being part of a company where one's work is valued enough to receive compensation in return, and this value cannot be replaced by receiving charity instead. ${ }^{17}$ There is value in taking a loan that one is confident one can pay back, and value in paying a loan back with the knowledge that one is credit-worthy to receive a loan in the future. Being declined credit comes with a shame that is beyond the frustration of having less capital to invest. And there is value in romance; few buy a potential partner dinner only to receive dinner back, and few are excited to give a gift because they expect a gift back. It is the relationships that dinners and gifts make possible that is of value, and not the dinner and gifts themselves.

Just as the shadow of the future is important for reciprocity in home countries, the shadow of the future is important for reciprocity in host countries. For an employer to invest in training a refugee for a job, she must know the refugee will be around to produce profit for the firm in the future. For a bank to provide credit to a refugee, it must know the refugee will be around to pay the loan back. And for a potential longterm romantic partner to invite a refugee out for a drink the first time, it helps if she knows the refugee will be around to offer a drink back, and to then accept another date even later, and then to offer another date later still, until the dating stage is over, and a more serious relationship unfolds.

When refugees are forced to flee their home countries, and arrive in host countries, they are often caught between two worlds: one where they struggle to form reciprocal relationships in their home countries because others are not sure if they will survive, and another where they struggle to form reciprocal relationship in their host countries 
because others are not sure if they will remain. If the reason refugees have a right to asylum is because they have a right to life and liberty, and securing life and liberty is valuable partly because it makes possible relationships, there is good reason to ensure that refugees can access relationships through reciprocity. The conditions for reciprocity are enhanced if citizens perceive a shadow of the future, in that they know refugees will likely remain, rather than be forced to leave any day.

If this is true, there are two implications. One is that host states ought to permit refugees to remain so long as returning is unsafe, rather than requiring them to move from country to country every few years. Even if this policy ensures refugees' survival, it denies them the shadow of the future for reciprocity, thus decreasing the chances of entering even short-term relationships with others.

Moreover, it would be wrong to require that refugees return home once returning home is safe. This is because, if refugees are forever in a position where they can be required to return any day, this diminishes others' willingness to enter reciprocal relationships in the present. This phenomenon was apparent in Israel, where I interviewed refugees from Eritrea who struggled to access credit, housing and the types of jobs requiring training. Creditors, landlords, and employers were uncertain that Eritrean refugees would be permitted to remain, and so were unsure whether refugees would be able to pay back loans, pay rent, or continue working in the future. Were creditors, landlords, and employers certain that refugees would be able to remain in the future, they would be more willing to provide them credit, housing, and jobs in the present. In other words, refugees ought to be given visas that extend into a period when returning is safe, so that they can enter reciprocal relationships when returning is unsafe. Only then will they have access to the reciprocity that makes even short-relationships possible, the sort of relationships that provide housing, finance, friendship, and range of other goods.

It is important to emphasize that, though refugees have a right to the conditions of reciprocity, this right is not absolute. It might only arise if a state could provide these 
conditions at below a given cost. If a state faced a large and sudden increase in the number of refugees arriving, and providing these refugees the right to remain entailed high costs, perhaps it would be permitted to sacrifice refugees' access to reciprocity by requiring them to return home once returning was safe. In this sense, the right to remain is similar to other sorts of rights that refugees are given. Normally, we claim that refugees have a right to medical care and education, in that the state has a duty to provide them these rights if the costs fall below a given threshold. If a state faced a very large and sudden influx of refugees, perhaps it would be permitted to deny healthcare and education. But states that can provide healthcare and education at low costs have an obligation to do so, and cannot appeal to their right to control immigration to act otherwise. Similarly, states that can provide refugees visas to remain have an obligation to do so if costs fall below a given threshold, and cannot appeal to their right to control immigration to act otherwise.

The above argument does not establish precisely how many years a government ought to allow refugees to remain after returning home is safe. We might imagine a government that permitted refugees to remain not indefinitely, but for five to ten years after returning was safe. This would create a relatively long shadow of the future during the period when returning was not safe, and if citizens were not certain when refugees would leave, this would help refugees to enter reciprocal relationships during this unsafe period. For example, in 1998 it was relatively safe for some Rwandan refugees to repatriate from Uganda, but the Ugandan government nonetheless permitted many Rwandan refugees to remain for several years longer, requiring them to return only in 2013. ${ }^{18}$ If all Ugandan citizens in 1994 were aware that Rwandans would never be forced to return without a five-years notice, and that some would be permitted to remain indefinitely, then Ugandan citizens would perceive a longer shadow of the future, encouraging them to enter reciprocal relationships with refugees when returning was still unsafe.

Contrast this to Germany' policy in 1995, when immediately after the Dayton Peace Accord it required all refugees from the former Yugoslavia to repatriate. Germany is 
planning a similar policy for Syrian refugees, who will be required to return home the moment returning is safe (Martinovic, 2016). If the German government permitted refugees to remain for five to ten years after returning was safe, this would help Syrians access a range of relationships. A Syrian refugee living in Germany today could be confident that, even if Syria became safe tomorrow, she could stay for at least some years, and each German citizen could be confident that each Syrian refugee could stay for at least some years, encouraging enough of a shadow of the future for reciprocal relationships to unfold.

If refugees have a right to remain in a single country, and the right to remain even when returning is safe, this has an important further implication: many refugees may live enough time in the country that they will become social members. Many will therefore begin to have claims to citizenship, and once they have citizenship, they will have a right to remain indefinitely. In other words, reciprocity explains why refugees have a right to remain for some time after returning is safe, and social membership explains why refugees are permitted to remain indefinitely once they have remained long enough. While not all refugees will remain long enough to become social members, many will. ${ }^{19}$

For example, imagine that the Ugandan government assured all South Sudanese refugees currently in the country that, even if the South Sudanese Civil War ended tomorrow, they would have another five years to remain in Uganda. The Ugandan government would be creating a policy that allowed South Sudanese to live in Uganda for at least five years, and likely far longer. If refugees ended up living in Uganda for long enough, they would no longer have a mere right to remain for reciprocity alone, but because of the additional right to citizenship. And once they held this right, they would have a derivative right to remain indefinitely.

\section{Three objections}

There are, broadly speaking, three potential objections against the above argument. 


\subsection{Reciprocity is not very important}

Some might claim that the goods I describe - the goods of credit, jobs, romance, friendship, etc. - are not basic rights, and so even if refugees would benefit from the goods reciprocity provides, refugees do not have a right to remain. Or some might suppose reciprocity itself is not terribly important, even if it makes possible other goods we value. One reason for supposing reciprocity is not important is that people voluntarily leave their homes, jobs, credit unions, and romantic partners all the time. If reciprocity truly had great value, then presumably individuals would declare in advance their intention of never leaving their homes, jobs, credit unions, and partners. Individuals rarely make such declarations.

While individuals rarely declare their intention of never leaving their home, relationship, and so forth, they also rarely announce beforehand that they intend to soon leave their home, relationship, and so forth. New tenants rarely declare that they only intend to rent for six months, new employees rarely declare that they will definitely leave their job after a year, and new romantic partners rarely declare that they intend to leave their beau in exactly two years' time. Even declaring, 'I'll probably break up with you in a decade' is not to be advised. It is the chance that one will remain which provides a shadow of the future, and the higher the chance the longer the shadow. It is the chance that refugees will remain which provides citizens the shadow of the future, and the higher the chance the longer the shadow. If refugees have no or low chances of remaining when returning is safe, then refugees lack what many of us take for granted: the ability to easily form relationships dependent on reciprocity.

Moreover, even if the sorts of relationships dependent on reciprocity are not basic rights - even if refugees do not have a right to romance, credit, jobs, and so forth - the options of trying to access romance, credit, and jobs are basic rights. More specifically, they are the sorts of rights widely accepted as belonging to refugees. It is widely accepted that refugees ought to be given the same legal rights afforded to temporary residents (da Costa, 2006), and temporary residents tend to have access to credit if a borrower is willing to lend, romance if a partner is willing to reciprocate, and jobs if 
an employer is willing to hire. If refugees have a right to try accessing credit, romance, and jobs because these goods have value, but refugees lack the practical ability to access these goods because the shadow of the future is short, there is reason to extend this shadow and let refugees remain. In other words, just as refugees ought to be given the legal right to access a range of goods, refugees ought to be given the legal right to remain to access these goods.

To see the force of this claim, it is worth comparing the right to remain with the right to movement within states. Imagine a refugee had the legal rights of residents - she could work if she found an employer, marry if she found a partner, worship if she found a mosque and so forth - except she could not leave a given remote town. Her access to the legal rights of residents would have little value if her town lacked businesses, social activities, places of worship, and other institutions that protected her ability to access jobs, make friends, and worship with co-religionists. Just as this spatial constraint makes her right to various goods of little value in practice, her temporal constraint - requiring that she leave within a specified number of years makes her right to various goods of little value in practice. This provides a good reason to lift this temporal constraint, giving her the right to remain.

\subsection{All individuals benefit from reciprocity}

There is a second objection to my argument. Some might note that all individuals benefit from reciprocity, including non-refugee students, migrants, tourists and so forth. If merely benefiting from reciprocity implied one had a right to reciprocity, and this implied one had a right to remain, then all students, migrants, and tourists would have a right to remain. This raises a problem: the entire purpose of this article was to consider why refugees have a right to remain even if others do not. If others do have a right to remain because of reciprocity, this implies that states do not have broad rights to control immigration. If we think states do have broad rights to control immigration, but refugees still have a right to remain, we must explain why. In other words, we must explain why refugees are special, and the Reciprocity Argument does not. 
Though all benefit from reciprocity, this does not indicate that all individuals have a right to remain. This is because most individuals can access a relatively long shadow of the future in their home states, given that they do not face a high risk of death and displacement in their home states. If most can access reciprocity in their home states, then most can access at least short-term relationships in their home states, and so they do not have a right to remain in their adopted host states. This is similar to the approach we take regarding other government-provided rights. When I was a student in the UK I did not have a right to government-provided welfare provisions, because I could access such basic welfare in my home state. It is the fact that refugees cannot access welfare provisions in their home states - because they will risk death or persecution if they return - that partly explains why refugees have a right to welfare provisions in host states. The same can be said about refugees' right to reciprocity in host states.

Of course, it may be that reciprocity is not like the right to welfare provisions; it is more comparable to the right to family life. A student usually has a right to bring their children and spouse with them if they study in a foreign country: the fact that they could access their family at home does not preclude their right to access family abroad. Perhaps the right to reciprocity is similar, and should be granted to all, thus giving all the right to remain. While this may be true, it remains the case that refugees' particular inability to access reciprocity in their home countries provides one reason to permit them to remain, a reason that does not apply to others.

\subsection{Permits deporting citizens}

A final objection to my theory is that it seems to imply that, if states have broad right to control immigration, with an exception only given for those who cannot access reciprocity elsewhere, then a state would be permitted to require its own citizens to leave if they could find reciprocity abroad. The Canadian government could force a Canadian citizen to move to the US if this citizen also had US citizenship; the citizen 
would not need a long shadow of the future in Canada if she could gain a long shadow in the US.

This is not the implication of my argument, because there are other reasons individuals might have a right to conditions for reciprocity where they are. If an individual is a citizen in her current country of residence, then she might gain the right to reciprocity with her co-citizens, because reciprocity with one's co-citizens has value distinct from reciprocity in general. My argument is simply that, if someone lacks reciprocity in general, because the risk of death and persecution in their home countries is high, they have a right to asylum that protects their access to reciprocity in general. This can be only obtained by remaining in their adopted country, a scenario applicable to refugees.

\section{Conclusion}

It is widely accepted that states have a right to control who enters their territory, but that refugees are an exception. If states have a general right to control immigration, but must accept refugees needing asylum, perhaps states may require that refugees return once no longer needing asylum.

I presented an objection to this claim: refugees who have lived for many years in the country take on certain ties that give rise to new moral claims, including the claim to citizenship. With citizenship comes the right to remain indefinitely, even after returning is safe. This argument, commonly evoked in Western democracies, is incomplete: it does not establish why refugees have a right to remain in a given country during the period when they require asylum. We might imagine a policy where refugees were required to move from country to country every five years, forever obtaining asylum, but never obtaining the ties that are necessary for obtaining citizenship. We need an argument for why such a policy is wrong.

One reason such a policy might be wrong is that, if refugees are required to move every five years, then they will struggle to plan for the future, and planning for the future is often necessary to build social relationships with others. Social relationships 
have value, and so letting refugees remain has value. Though social relationships have value, it is not clear why refugees cannot gain social relationships that last a limited number of years, and plan for a future where they will be require to move every few years.

I presented a novel argument that explained why such a policy would be wrong, and why refugees have a right to remain when returning is safe. Refugees have a right to remain in one country, and to remain when returning is safe, to develop reciprocal relationships during a period when remaining is unsafe. A refugee in Germany who cannot safely return to Syria will struggle to obtain a loan if a lender is not certain when the refugee will be required to leave. A refugee in Sudan who cannot safely return to Eritrea will struggle to start a romantic relationship if potential partners are uncertain when the refugee will be required to leave. Refugees have a right to remain so that citizens can be fairly certain they will remain, assisting them to enter relationships in the present.

\section{Works Cited:}

1951 Convention and 1967 Protocol Relating to the Status of Refugees, available at http://www.unhcr.org/3b66c2aa10.html, accessed 23 March 2016.

AA (Article 15(c)) Iraq CG [2015] UKUT 00544 (IAC), Upper Tribunal (Immigration and Asylum Chamber).

Axelrod, R. (2006). The evolution of cooperation: Revised edition. New York: Basic Books.

Becker, L.C. (2005). Reciprocity, justice, and disability. Ethics 116(1), 9-39

Betts, A. (2010). Survival migration: A new protection framework. Global Governance 16(3), 361382.

Bickenbach, J.E. (2012). Current issues, controversies and solutions. In J. E. Bickenbach and G. L. Albrecht (eds.), Ethics, law and policy (pp. 67-137). USA: Sage.

Carens, J. (1987). Aliens and citizens: The case for open borders. The Review of Politics, 49(2), 251-273

Carens, J. (2013). The ethics of immigration. Oxford: Oxford University Press.

Cartagena Declaration on Refugees, 1984, accessed on 18 January 2019 at https://www.unhcr.org/about-us/background/45dc19084/cartagena-declarationrefugees-adopted-colloquium-international-protection.html

Carter, M. (2008). Deportation from UK of refused HIV-positive asylum seeker to Uganda does not breach human rights, European Court rules. Aidsmap, 27 May 2008, accessed on 12 August 2018 from http://www.aidsmap.com/Deportation-from-UK-of-refusedHIV-positive-asylum-seeker-to-Uganda-does-not-breach-human-rights-EuropeanCourt-rules/page/1430455/ 
Cherem, M. (2016). Refugee rights: against expanding the definition of 'refugees' and unilateral protection elsewhere. Journal of Political Philosophy 24(2), 183-205

Devictor, X. and Do, Q. (2016). How many years do refugees remain in exile? World Bank 15 September 2016, accessed on 4 September 2018 at http://blogs.worldbank.org/dev4peace/how-many-years-do-refugees-stay-exile

Federal Office of Migration and Refugees, 'Naturalization in Germany,' accessed on 11 September 2017 at http://www.bamf.de/EN/Willkommen/Einbuergerung/InDeutschland/indeutschlan d-node.html

Fleischer, D.Z. and Zames, F. (2001). The Disability Rights Movement: From Charity to Confrontation. Philadelphia: Temple University Press.

Gibney, M. (2004). The Ethics and Politics of Asylum. Oxford: Oxford University Press.

Gil-Bazo, M. (2015). Refugee protection under international human rights law: From nonrefoulement to residence and citizenship. Refugee Survey Quarterly 34(1), 11-42.

Goodin, R. (1991). Compensation and redistribution. Nomos 33, Compensatory Justice 33, 143177.

Grahl-Madsen, A. (1972). The status of refugees in international law, 11

Hamilton, R. (20130. Kenya to repatriate Somali refugees. BBC News, accessed on 12 September from http://www.bbc.co.uk/news/world-africa-20819462

Harding, R. (2016). Japan opens door to temporary foreign workers. Financial Times 14 September, accessed on 3 November 2017 at https://www.ft.com/content/21a5aef87a4d-11e6-b837-eb4b4333ee43;

Hathaway, J. C. and Neve, R. A. (1997). Making international refugee law relevant again: A proposal for collectivized and solution-oriented protection. Harvard Human Rights Journal 10, 115-211.

Hidalgo, J. (2015). Resistance to unjust immigration restrictions. Journal of Political Philosophy 23(4), 450-470

Kingston, L.N. (2017). Bringing Rwandan refugees 'home': The cessation clause, statelessness, and forced repatriation. International Journal of Refugee Law, 29(3), 417-437.

Kittay, E. (1999). Love's labor: Essays on women, equality, and dependency. New York: Routledge.

Lister, M. (2013). Who are refugees? Law and Philosophy, 32(5), 645-671.

Martinovic, M. (2016). Refugee reloaded: Lessons from German's approach to Bosnian War. DW, 2 February, accessed on 3 November 2017 at http://www.dw.com/en/refugeesreloaded-lessons-from-germanys-approach-to-bosnian-war/a-19021249

Miller, D. (2005). Immigration: The case for its limits. In A. Cohen and C. Wellman (eds.), Contemporary Debates in Applied Ethics, Malden, MA: Blackwell Publishing

Miller, D. (2016). Strangers in our midst: The political philosophy of immigration. Cambridge: Harvard University Press.

Nine, C. (2018). The wrong of displacement: The home as extended mind. The Journal of Political Philosophy, 26(2), 240-257

O'Reilly, A. (2017). The right to decent work of persons with disabilities. International Labour Organization.

Oberman, K. (2016). Immigration as a human right. In S. Fine and L. Ypi (eds.), Migration in Political Theory: The Ethics of Movement and Membership. Oxford: Oxford University Press 2016.

OECD, 'International Migration Outlook: Sopemi 2011,' accessed on 3 November 2017 from https://www.oecd.org/migration/48351304.pdf

Omata, N. (2011). 'Repatriation is not for everyone': The life and livelihoods of former refugees in Liberia. New Issues in Refugee Research, UNHCR Working Papers 213.

Organization of African Unity, Convention Governing the Specific Aspects of Refugee Problems in Africa, 1969, accessed on 18 January 2019 at 
https://www.unhcr.org/about-us/background/45dc1a682/oau-conventiongoverning-specific-aspects-refugee-problems-africa-adopted.html.

Owen, D. (2016). In loco Civitas: On the normative grounds and character of the institution of refugeehood and of responsibilities towards refugees. In S. Fine and L. Ypi (eds.), Migration in political theory: The ethics of movement and membership. Oxford: Oxford University Press.

Rinke, A. (2016). German's Merkel says refugees must return home once war is over. Reuters, 30 January, accessed on 12 September from http://www.reuters.com/article/useurope-migrants-germany-refugees/germanys-merkel-says-refugees-must-returnhome-once-war-is-over-idUSKCNOV80IH

Rosa da Costa, (2006). Rights of refugees in the context of integration: Legal standards and recommendations. Legal and Protection Policy Research Series, Division of International Protection Services, United Nations High Commissioner for Refugees, accessed on 19 August 2018 at http://www.unhcr.org/44bb90882.pdf

Rubio-Marin, R. (2000). Immigration as a Democratic Challenge: Citizenship Inclusion in Germany and the United States. Cambridge: Cambridge University Press.

Sangiovanni, A. (2007). Global justice, reciprocity, and the state. Philosophy and Public Affairs, 35(1), :3-39.

Shachar, A. Ch. 6 in The Birthright Lottery: Citizenship and Global Inequality, Cambridge and London: Harvard University Press 2009

Shacknove, A. E. (1985). Who is a refugee? Ethics 95(2), 274-284.

Stilz, A. (2011). Nations, states, and territory. Ethics, 121, 572-601

Stilz, A. (2013). Occupancy rights and the wrong of removal. Philosophy and Public Affairs, 41(4), 324-356.

U.S Citizenship and Immigration Services, 'Refugees,' accessed on 11 September 2017 at https://www.uscis.gov/humanitarian/refugees-asylum/refugees

Walzer, M. (1983). Spheres of justice: A defence of pluralism and equality. New York: Basic Book.

Weiler, A. M.; McLaughlin, J.; Cole, D.C. (2017). Food security at whose expense? A critique of the Canadian temporary farm labour migration regime and proposals for change. International Migration 55(4), 48-63.

Wellman, C. H. (2008). Immigration and freedom of association. Ethics, 119(1), 109-141.

Ziegler, R. (2017). Voting Rights for Refugees. Cambridge: Cambridge University Press.

Notes:

${ }^{1}$ When I write 'widely accepted' I mean that philosophers widely accept this claim, though of course non-philosophers may also widely accept this claim. For philosophers defending this claim, see Gibney, 2004; Miller, 2005; and Wellman, 2008.

${ }^{2}$ There is debate over why states must accept refugees, but one common reason is that states must accept refugees because they have humanitarian duties towards those outside their borders, and humanitarianism requires us to protect individuals at risk in their home countries. This moral responsibility, it is worth noting, is not the same as states' legal responsibility. Legally, states need only provide protection to those fleeing persecution. For a defense of this moral rule, see Carens, 2013, pp 192-224; Gibney, 2004; Hidalgo, 2015; Miller 2005, p 202. It is worth nothing that some states also accept this moral responsibility, at least to an extent. See Betts, 2010. 
${ }^{3}$ It is worth noting that my argumentation may persuade you that refugees have a right to remain even if this undermines citizens' access to survival. Nonetheless, my goal here is to demonstrate that refugees at least have a right to remain in the non-absolute sense, where the right can be overridden when it conflicts with some citizen needs.

${ }^{4}$ Carens is less explicit regarding this, but seems to suggest that restricting immigration may be justified to protect public order, even though today's levels of restrictions far surpass what is necessary to protect public order.

${ }^{5}$ For example, of the millions currently fleeing Iraq and Syria, many are fleeing war rather than persecution based on their identity. See AA (Article 15(c)) Iraq CG [2015] UKUT 00544 (IAC), Upper Tribunal (Immigration and Asylum Chamber).

${ }^{6}$ For example, the Organization of African Unity Governing the Specific Aspects of Refugee Problems in Africa (1969, p. 3) provides asylum to those who are fleeing 'external aggression, occupation, foreign domination or events seriously disturbing public order,' including accidental events for which no agent is to blame. Similarly, the EU provides subsidiary protection to those who have fled general violence, and the Cartagena Declaration (1984, p. 36) in Latin America provides asylum to 'persons who have fled their country because their lives, security or freedom have been threatened by generalized violence, foreign aggression, internal conflicts, massive violation of human rights or other circumstances which have seriously disturbed public order.'

${ }^{7}$ For related arguments, see Owen, 2016 and Shacknove, 1985, pp. 278-280.

${ }^{8}$ I have never come across this particular argument, but Ruvi Ziegler defends refugees' legal right to vote for a similar reason. See Ziegler, 2017.

${ }_{9}^{9}$ Some might suppose that providing voting rights without citizenship would create two classes of voters, and make those without citizenship susceptible to blackmail by those with full citizenship. This argument would require a broader discussion on blackmail, and when and why it is wrong, which I lack the space to address here.

${ }^{10}$ The reason that governments ought to grant citizenship based on how long an individual has lived in the country, and not literally based on how many friends they have, is because this is less intrusive; the government needn't call up immigrants' friends and romantic partners to find out just how good a friend and partner they are, deporting those who are mediocre friends and partners.

${ }^{11}$ This general principle - that social ties give rise to citizenship claims - is supported by a range of philosophers. See Carens, 2013, Ch. 8; Miller, 2016, Ch. 7; and Shachar, 2009, Ch. 6.

${ }_{12}$ A version of this argument has been raised by legal scholars. See Grahl-Madsen, 1972, p. 442, cited by Gil-Bazo, 2015.

${ }^{13}$ For example, Lawrence C. Becker writes that 'Reciprocity is a matter of making a fitting and proportional return for the good or ill we receive.' Similarly, Eva Kittay provides a broad conception of reciprocity distinct from the one I have in mind: 'Just as we [ourselves] have required care to survive and thrive, so we need to provide conditions that allow othersincluding those who do the work of caring - to receive the care they need to survive and thrive.' See Becker, 2005, p. 18; Kittay, 1999, pp. 106-109; Sangiovanni, 2007, pp. 20-21.

${ }^{14}$ Others have noted that such reciprocity could have evolved throughout human biological history. My argument is not based on such empirical claims: I merely claim that some relationships depend on the sort of reciprocity described by evolutionary biologists and psychologists. See Axelrod, 2006.

15 This is not merely theoretical. In the UK, lenders will rarely provide a loan to those who have fewer than five years on their visa, partly because those who have more than five years on their visa will have the option of later applying to remain indefinitely. The shorter the shadow of the future, and the more knowledge of precisely when the relationship will end, the less likely a lender will give any loan at all, let alone a succession of loans over a long period of time. 
${ }^{16}$ Of course, not all reciprocal relationships are in the interests of participants. A loan could leave the borrower in permanent or long-standing debt which makes her worse off than if no loan was provided at all. But it remains the case that access to regular loans can be essential to making ends meet or growing one's business.

${ }_{17}$ On a broader understanding of reciprocity, charity could be thought of as reciprocal: If everyone gives to charity, then everyone will have access to charity should the need arise, even if few will literally receive charity from the individuals whom they donated to in the past. But even if charity is a form of indirect reciprocity, many still prefer not relying on charity, and prefer to be in employment with more direct reciprocity of the kind I have in mind. For this reason, disability rights activists emphasize that those with disabilities should not simply be given food, shelter, and care; they should be given the opportunity to contribute to society and be compensated for such contribution, assuming such reciprocity is possible. For a discussion on indirect reciprocity in the form of charity, see Becker 2005 at 20-21. For a discussion disability rights and charity, see Bickenbach, 2012, pp. 67-137, especially 92-95; Fleischer and Zames, 2001; O'Reilly, 2017.

${ }^{18}$ It is important to note that in 2013 many were required to repatriate who would face lifethreatening conditions in Rwanda, and so Uganda hardly implemented a just refugee policy. It nonetheless is true that some refugees could have returned earlier, but were not forced to do so until 2013 (Kingston, 2017).

${ }_{19}$ Precisely how many will depend on how long the conditions in home countries remain unsafe. As of 2018, at least half of all refugees have been in exile for over four years, and many in the other half only returned due to unjust deportations and repatriation. So it seems likely that the majority of refugees, if they can remain in one location during their asylum because of the Reciprocity Argument, they can gain Citizenship based on the Social Membership Argument. For a discussion on the number of years refugees remain in exile, see Devictor and Do, 2016. 